\title{
MEDO E MEMÓRIA: EMOÇÃO E SOCIABILIDADE DO FINAL DO SÉCULO XX (1950-2000)
}

\author{
FEAR AND MEMORY: EMOTION AND SOCIABILITY IN THE LATTER HALF OF THE 20TH \\ CENTURY (1950-2000)
}

Marilza Mestre ${ }^{1}$

\begin{abstract}
RESUMO
O medo é uma emoção que acompanha o ser humano desde sempre e que vem se manifestando de forma diferente para homens e mulheres e de cultura para cultura ao longo do processo histórico. No presente artigo, analisa-se o depoimento de uma mulher de 68 anos, que durante a entrevista reconstruiu, a partir de suas lembranças, parte da memória comum ao tempo por ela vivido. A categoria de análise criada, composta de duas vertentes: os medos existenciais e os sociais, focou-se nos medos por ela relatados, à luz da historiografia de autores como Delumeau, Duby, Zeldin, Ariés, Lebfreve e Chauí.
\end{abstract}

Palavras-chave: medo; emoções; memória e história oral.

\begin{abstract}
Fear is an emotion that has accompanied mankind ever since its origins and which has manifested itself in diffe- rent ways in men and women and in different cultures throughout history. This article provides an analysis of the testimony of a 68 year old woman who, during an interview, reconstructed from her own memories part of the memories that are also common to the period on which she lived. The category of analysis created, comprised of two elements: the fears of the experience of living and the fears found in society, focussed on the fears narrated by her, in the light of the historiography of authors such as Delumeau, Duby, Zeldin, Ariés, Lebfreve and Chauí.
\end{abstract}

Key words: fear; emotions; memory and oral history.

\section{INTRODUÇÃO}

Ao longo da história do homem, o medo foi, muitas vezes, apontado como a causa de uma série de comportamentos. Mas sendo ele, como as outras emoções, construído pela sociedade e tendo função descritiva das relações que nela ocorrem, entende-se ser o medo não uma causa, mas um processo passível de análise que possibilite a reconstrução de parte da sociabilidade vivida.

Um estudo clássico sobre a questão do medo nas sociedades ocidentais é o de Jean Delumeau, para quem os indivíduos tomados isoladamente ou as coletividades e as próprias civilizações estão comprometidos com um diálogo permanente com o medo. O que se fala do medo, ou até mesmo o não falar dele, pode ser símbolo da maneira como a sociedade constrói os valores de cada época. Delumeau se pergunta: "Por que esse silêncio prolongado sobre o papel do medo na história?" E ele mesmo responde: [...] o discurso escrito e a língua falada tiveram por muito tempo a tendência de camuflar as reações naturais que acompanham a tomada de consciência de um perigo [...] (Delumeau, 1996, p. 93).

Tradicionalmente, o medo esteve associado ao feminino, pois aos homens era negado o direito de demonstrar "fraquezas", e era considerado como uma emoção "menor". Por outro lado, às mulheres era mais que permitido demonstrar sua "fragilidade", era mesmo incentivado, e possuía conotação valorativa da mulher enquanto seres "sensíveis e delicados".

\footnotetext{
${ }^{1}$ Psicóloga clínica no CPEM - Centro de Psicologia Especializado em Medos/ professora de Psicologia na UTP e na PUC-PR. Doutoranda em História na UFPR. End. para correspondência: Cpemedos@cwb.matrix.com.br - Rua Vicente Machado, 320 - conj. 302 - Centro, CEP: 80040-010 Curitiba - PR.
} 
O século XX diferenciou-se dos anteriores, pela velocidade e intensidade das transformações socioculturais que o homem atravessa. Dentre elas, segundo Matos, 1996, é inegável a transformação que a mulher sofreu e produziu nas práticas cotidianas, na socialização e na (re)construção da identidade social de gênero, que se modifica nas diversas culturas, etnias e tempo histórico.

De acordo com Saffioti, 1979, os primeiros trabalhos sobre a história das mulheres possibilitaram descortiná-la nas suas relações cotidianas, principalmente em seu trabalho fora de casa. O tema comum àquelas pesquisas era a busca de uma identidade específica da mulher, trabalhando a idéia de que o "ser mulher" implicaria possuir características constantes e permanentes a todo esse grupo, em que haveria uma "essência" do ser feminino. Além disso, era comum, nessa fase, delatar-se o jogo de poder nas relações entre homens e mulheres. Hoje o estudo de gênero preocupa-se em descobrir e analisar as relações sociais entre masculino e feminino e suas transformações de forma dinâmica e como essas criam novas formas de sociabilidade e de ocupação de espaço por seus atores.

Em função dessas novas abordagens é mais fácil, agora, analisar o efeito do perigo, a reação de fuga ou ataque em face daquilo que se considera perigo, e que não se manifesta igualmente nas pessoas. É bem verdade que todos são suscetíveis ao medo, mas o que atinge a uns não necessariamente tem o mesmo resultado nos outros. Não há dúvida, além disso, que o medo desencadeado em uma pessoa afetará sua relação com as outras, do mesmo modo que o medo nascido de valores sociais constrói medos individuais. Estudos mais recentes, como, por exemplo, o de Guinzburg, sobre a história das pessoas comuns, começam a revelar que o crescimento humano só foi possível mediante a relação entre os diferentes grupos sociais, entre o mundo adulto e infantil, entre o homem e a mulher.

O presente artigo desenvolveu-se a partir da análise de um depoimento prestado por uma mulher que se propôs a falar de si, das suas experiências. Ao responder às perguntas da pesquisadora, aos poucos, sua trajetória de vida foi se descortinando desde a mocidade até a idade madura.

Baseado em um único depoimento, o artigo tenta revelar os medos que aparecem no relato da entrevistada ${ }^{2}$. Duas vertentes de análise tentarão identificá-los: a primeira diz respeito aos medos aqui nomeados de "permanentes", por se tratar daqueles compartilhados por todos os seres humanos e, portanto, considerados como "universais". O medo da morte, da perda, do desconhecido, são esses medos que Delumeau identifica como permanentes, que podem sofrer mudanças na sua forma de expressão, mas não há homem que não os tenha sentido. A segunda, trata daqueles que aparecem conforme o contexto em que se esteja vivendo, que poderiam ser chamados de medos "sociais" e se referem sobretudo ao medo que a alteridade produz.

\section{OS MEDOS PERMANENTES}

Os medos permanentes eram mais freqüentemente compartilhados por indivíduos pertencentes a todas as categorias sociais [...] esses são, portanto, os medos da maioria. (J. de Delumeau, 1996, p. 19)

Foi o interesse pelas paixões humanas que levou a filósofa Marilena Chauí a pesquisar o sentido do medo. Pergunta ela: "De que se tem medo? Da morte, foi sempre a resposta. E de todos os males que possam simbolizá-la, antecipá-la, recordá-la aos mortais." (1987, p. 63)

Para Chauí, como para Delumeau, a insegurança está associada à morte, e a segurança, à vida. Os animais não temem a morte pois não são capazes de antecipá-la. O homem, no entanto, sabe que morrerá.

\footnotetext{
${ }^{2}$ Entrevista gravada no dia 06.08.2000: M. L. é uma dona de casa de 68 anos (nasceu em 1932) em Porto União (SC) e viveu até seus vinte anos em União da Vitória (PR); conheceu seu esposo por volta de seus 15 anos, ele estava com 17 e estudava Odontologia em Curitiba. Nascida em classe média alta, estudou até o $1^{\circ}$ ano da Escola Normal. Foi a segunda de uma prole de quatro irmãos. Sua mãe era paralítica por artrite reumatóide (doença que hoje acomete a depoente). Seus pais morreram na década de 1970. M. L. casou-se aos 20 anos. Aos 22 teve sua primeira filha (no ano de 54); perdeu dois filhos bebês (um menino, em 1957, e uma menina, em 58). Mudou-se para o interior do Paraná devido às perdas das crianças e à bronquite da mais velha. No ano de 1961, teve seu quarto filho. Em 1973 mudou-se para Curitiba e sua irmã mais velha morou com ela de 74 (após a morte do pai) a 86 e só saindo de lá ao se casar, meses após o casamento do filho caçula de M. L. A filha casara anos antes.
} 
Ariés (1977) lembra, porém, que o medo de morrer somente surgiria na sociedade do século XV. Até então falava-se da morte às claras e todos participavam de seu ritual com naturalidade. A partir daí a morte passou a ser negada, pois falar dela implicaria reconhecer a finitude dos seres. E é desse fim que os seres têm medo.

\subsection{A morte}

Durante o tempo de duração de sua entrevista, M. L., entre outros assuntos, falou de suas experiências com a morte, quando relatou um fato ocorrido por ocasião da morte da mãe e de como se sentira em face desse evento. Para vê-la, enfrentou uma longa viagem, cheia de ansiedade, mas não conseguiu chegar a tempo ${ }^{3}$.

"[...] e eu não vi a mamãe. Fiquei traumatizada. Porque quando eu cheguei aqui eles já tinham sepultado ela. Não deu para esperar, era muito longe ....Aí meu irmão e irmã deixaram a sepultura meio aberta para eu poder vê-la. Mas todo mundo disse que eu não deveria ver... Tive medo! Para ficar [silêncio]..."

A mensagem implícita na última frase é: ficar com a imagem da mãe ainda viva; guardar sua lembrança em vida. Afastar o confronto com a morte.

Ainda lembrando aquela ocasião, M. L. compara seu medo da estrada nas décadas de 1950 e 1970 com os medos de seu tempo presente; falava de seus medos de antes:

"Dava 9, 10 horas de viagem de carro. Pegamos caminhão de soja na estrada. Eu tinha medo daquela estrada, os caminhões de soja não respeitavam carros. Mas naquele dia era o medo de não chegar."

Falando da irmã, no ano de 2000:

"A minha irmã morre de medo de estrada; eu não, vou para a praia sossegada. Mas aquela estrada era braba e nas férias eu tinha medo porque os caminhões não deixavam passar. Hoje não, as estradas são asfaltadas, cuidadas, duplicadas, então é mais fácil ultrapassar."

O que aparece na fala de M. L. é uma transformação na percepção da possibilidade da morte. Ela relata três momentos diferentes em relação à morte na estrada: um, que diz respeito às viagens comuns, das férias, na década de 1950, as que fazia desde que fora morar no interior do PR, longe dos pais. Naquela época as estradas eram percebidas por ela como passíveis de produzir a morte, portanto geravam medo. Num segundo momento - década de 1970 - , relembra o dia da morte da mãe e o medo dividido, o conflito entre três grandes medos: o da morte (a estrada é perigosa), o da perda (a família morrer) e outro implícito, que é social (chegar a tempo para o enterro). Num terceiro momento (ano 2000), finalmente ela compara o medo daquela época e o atual medo da irmã, inferindo que esse medo atual é desnecessário, pois não há mais grandes perigos. A morte na estrada duplicada não é algo provável.

É visível, ainda, o seu medo da morte quando comenta, posteriormente, sobre os problemas graves que teve no nascimento de dois filhos (dos quatro que teve) que morreram logo após o nascimento. A segunda gravidez foi complicada por uma hemorragia, e a decisão foi por uma cesárea, algo incomum na década de 1950. Ela relembra aquele momento:

"Eu podia ter morrido e deixar a menina sozinha, sem mãe. Eu tinha medo de morrer e do neném também morrer. Eu dizia para o médico: não me deixe morrer, eu tenho uma filha para criar."

Aqui aparece outro medo que costuma estar associado à possibilidade de morte, própria, ou daqueles a quem se ama. A sensação de perda de algo ou de alguém que faz parte de sua vida.

\subsection{A perda}

\footnotetext{
${ }^{3}$ M. L. está relatando fatos de 1972. Ela morava no interior do Paraná desde 1958.
} 
Temer perdas também é um mecanismo que se liga a certo tipo de morte, não a biológica dessa vez, mas a pior delas que é a de perder pessoas, situações ou objetos significativos. Há ocasiões em que a própria morte pode ser preferível a perder aquilo que se ama.

Segundo Ariés (1977), o século XIX foi um período em que se acentuou o sentido do luto e conseqüentemente da perda, mostrando simbolicamente que os sobreviventes tinham mais dificuldade em aceitar a morte do outro do que o faziam anteriormente. A morte temida não era só a própria morte mas também a do outro.

$\mathrm{O}$ relato de M. L. é pleno de situações em que ela sofreu perdas significativas e temia voltar a perder, além de como esse medo afetou sua relação com os filhos. Remetendo-se à década de 1950, ela fala da morte dos dois filhos: o bebê de 3 meses por broncopneumonia e outro de 45 dias, por encefalite.

“...fiquei muito revoltada. Ele não era nem para viver. Quando estava no sétimo mês tive uma hemorragia muito grande e o médico quis tirar. Tive que ficar deitada, em repouso quase três meses, para segurar. Eu não queria tirar. Tive que agüentar até o fim. Aí fui para o hospital, ele nasceu e viveu só três meses e eu perdi ele. Eu pensava comigo: Como? Eu fiquei deitada na cama, e ele morrer. Por que Deus me tirou ele?"

A dor dessa perda é retomada quando relata a morte da outra criança:

"a terceira gravidez foi a melhor que tive. [...] não me passava pela cabeça perder outra. E perdi ela com 45 dias [choro]."

Associado a essas perdas, vem o medo que a transformou numa mãe vigilante e onipresente na vida da filha mais velha (essa tinha bronquite), a ponto de o casal preferir abandonar o conforto da proximidade da família de ambos e a segurança financeira que o marido recém construíra ao fazer sua clientela de odontologia. Mudaram-se para o Norte Novo, onde não tinham nada, a não ser espaço para construir uma nova vida e preservarem-se da perda da filha. Ela conta como foi esse período, em relação aos cuidados com a mais velha:

"A R. só deu preocupações quando era pequena, com a bronquite [...] fiz tanta simpatia, cuidei tanto dela. Graças a Deus nunca mais teve nada. [...] a preocupação era com ela. Com a recuperação da saúde. A gente ainda estava com trauma da perda dos dois filhos."

Esse relato remete aos fins dos anos 50, início da década de 1960. Em 1961 nasceu seu último filho. A gravidez foi boa, o parto foi normal, a criança nasceu perfeita e com saúde. Mas assim mesmo o medo estava lá, assombrando o casal, principalmente essa mãe que se tornara superprotetora durante todo o primeiro ano de vida da criança. Além disso, seu médico resolveu fazer laqueadura como forma de preservar sua saúde mental. Tinha dois filhos pequenos para criar e a depressão ameaçava atingi-la pelo medo de ver as crianças mortas.

"quando ele nasceu eu fiquei traumatizada. Medo de perdê-lo, no início. [...] eu tinha impressão de que ele também... aí fiz laqueadura. O médico recomendou, eu estava com trauma dos outros dois filhos que tinha perdido. Não estava curada ainda. Foi difícil vencer isso. Fiquei assustada, ele tinha uma dorzinha qualquer eu corria para o médico, até os três meses dele [...] eu estava com tanto medo que ele me operou [...] até um ano mais ou menos eu fiquei receosa, depois fui melhorando."

Quando nasceu o quarto filho, saudável, ela passou a sofrer do "medo do medo da morte"; da possibilidade de perder mais uma vez. O medo da perda é, assim, um medo constante no relato de vida de M. L. A perda da figura materna parece remetê-la ao medo de perder de novo, o que transparece no pedido (ou seria recomendação?) feito ao marido durante a viagem para o enterro da mãe:

“...eu já não queria mais chegar e dizia: 'Á. (meu marido) vai com cuidado, vamos seguir como Deus quer. Se não der para chegar com tempo o que vamos fazer'?"

Essa forma de compreender a morte era algo corrente no pensamento da época. $\mathrm{Na}$ década de 1970, a revista O Cruzeiro ( $1^{\circ}$ de março de 1950, p. 114) apresentava um artigo da escritora Raquel de Queiroz que trazia uma reflexão sobre o modo como a humanidade lida com a morte e com a sensação de perda que ela traz. Diz ela: "Podemos muito bem imaginar a morte de alguém que amamos, e trememos de pavor autêntico ante essa evocação". Pode-se imaginar a dor daquele que fica, continua a autora, e o não saber como será o futuro sem o ser 
amado. O que por sua vez desencadeia uma nova angústia, a de sentir-se abandonado, frente ao desconhecido.

\subsection{O desconhecido}

O ser humano, de um modo geral, resiste a mudanças, pois mudar é encarar o novo, e isso provoca medo do desconhecido. A novidade causa receio tanto quanto suscita comportamentos exploratórios que têm a função de tornar o desconhecido algo previsível, sob controle. Para as mulheres, muitas das situações novas trazem desafios para elas e para aqueles com quem se relacionam.

O novo, o desconhecido, fala do imprevisível, do que não se conhece, e isso apavora as pessoas, pois, se a novidade pode trazer mais alegrias, pode também trazer destruição e morte. Para Delumeau (1996, p. 25-26), o medo de objetos ou de situações conhecidas é mais suportável do que a angústia do desconhecido. [...] Os nossos ancestrais temiam o mar, os lobos, os fantasmas e os presságios daquilo sobre que não se tem controle. Do ambivalente."

Durante a entrevista, M. L. deixa explícito seu medo daquilo que ela não conhece. Esse temor é claro quando fala do primeiro parto. Apesar de ter feito curso para parto sem dor, teve medo:

“...a gente tem aquele medo normal. [...] Medo de ter o filho, mas qual mãe que não tem? [...] um medo do que a gente não conhece. Era uma coisa desconhecida, o parto. A gente nunca tinha tido um filho."

Já no segundo parto, ela não tinha mais esse medo: o parto normal já lhe era conhecido. Quando o médico lhe comunicou que seria parto cesárea, um novo temor apareceu:

"Só não imaginava que ia para uma cesárea [...] foi dramático, muito dramático, eu estava vendo que não era uma coisa normal! Eu só soube na hora. Vi que não vinha normalmente e o médico falou que ia ser cesárea. Naquele tempo cesárea era algo raro."

Ela remete para outra maneira de sentir essa aversão pelo desconhecido que pode ser anúncio de perda e, ou, de morte. O diferente, o raro, pode ser perigoso. Por conta desse medo, muitas desgraças ocorreram ao longo da relação do homem com outros homens. $O$ estranho parecia hostil e podia oferecer perigo. E esse foi o motor de muitas guerras e sedições.

Lefebvre (1979) e Delumeau (1996), ambos se preocuparam em analisar o que se encontra na origem dessa inquietação coletiva pelo que se desconhece e é diferente daquilo que se acredita ser a verdade. Para livrar-se desse perigo, o homem pega em armas e, a pretexto de defender-se, passa a atacar o diferente. As regras sociais são alteradas, e a paz cede lugar a guerras, ao assalto; é a gestão da violência.

M. L. teme também a violência, como algo imprevisível e assustador, e diz que antes, quando era jovem, a violência não era assim. Fala da sua vida atual, dela como mãe de filhos adultos e como avó:

"[...] a gente não tinha essa preocupação quando os filhos da gente saíam. Tem que rezar para que eles cheguem em casa, logo e bem [...] eu fico toda noite rezando pelos meus netos. [...] até filho homem preocupa agora. Lógico. Como preocupa... (silêncio) por causa das drogas, não é?"

Ela teme as drogas, essa coisa desconhecida de sua realidade, mas que pode ser responsável pela destruição da vida de seus familiares.

Os medos que assombram aos seres humanos são amenizados no encontro do homem com o outro homem; ao viver em grupo, o homem se protegeu da própria morte, da perda que a morte dos seres amados significaria e do desconhecido que esses fatos trariam. Mas.... aumentou a possibilidade de outras transformações. Viver em grupo, em sociedade, solucionou alguns medos e criou outros, dessa vez construídos pela relação social: "quando as pessoas olharam além de seus arredores familiares, quando aprenderam a ler e a viajar, descobriram que muitos indivíduos estranhos compartilhavam suas emoções e interesses. [...] hoje, a esperança se sustenta acima de tudo, pela perspectiva do encontro com pessoas novas." (Zeldin, 1999, p. 122). As pessoas, ao perceberem de que havia partilha de emoções e crenças, tornaram o desconhecido conhecido, e foi exatamente aí que novos medos surgiram. 
"O inferno é o outro! [...] Se o outro existe, a existência do homem está ligada ao pensamento, ao julgamento que o outro faz de si." (Sartre, 1977, p. 22)

Agregando-se, o ser humano dá direito ao outro (diferente de si) de julgá-lo e ditar regras de convivência. E aí outros medos surgem: os historicamente construídos pelo homem nas suas relações sociais. "Medos novos se têm propagado sem cessar, em substituição aos que caíram em desuso, tal como o câncer e a AIDS sucederam à tuberculose e à sífilis." (Zeldin, 1999 , p. 161). Esses novos temores, socialmente construídos, apontam para situações que se evidenciam a partir da vivência grupal, que mudam de acordo com o contexto em que as pessoas se inserem e que são responsáveis pelo nascimento de comportamentos outrora inexistentes.

\subsection{Comportamento e aprovação social}

Segundo Zeldin (1999, p. 160), as razões para os povos, em todos os tempos e lugares, seguirem as regras sociais e adotarem esse ou aquele padrão de comportamento é a aprovação do 'outro'. "Uma parcela cada vez maior de pessoas se preocupa com o que os outros pensam delas [...] como cada ato, a cada dia, será criticado e julgado tanto por aqueles que as conhecem quanto pelos que as ignoram."

Ao longo da entrevista feita com M. L., a perda da aprovação social é algo que se apresenta recorrentemente como uma ameaça à tranqüilidade da entrevistada, situação que se evidencia, explícita ou implicitamente, em seu relato.

Já na década de 1950, em sua mocidade, essa condição se colocava em relação aos mores sociais impostos às moças solteiras de boa família, quando se evidenciavam alguns temores sobre a aprovação alheia:

"Naquele tempo a gente tinha tanto medo dos outros, a gente vivia sempre em função do que o outro pensa, do que eles observavam, do que eles criticavam. Não dava para dar mau passo."

Essa frase expressa um sentimento sobre o bem agir em sociedade. Os papéis sociais eram bem definidos e aceitos como "naturais". O olhar externo garantia isso. Máximas de comportamento moral dizendo o que a sociedade esperava das relações entre homens e mulheres, permitiam o controle da sociabilidade. Ao atender à expectativa do "outro", àquilo que a sociedade esperava do comportamento feminino e masculino, e ao corresponder à demanda social, os indivíduos garantiam a aprovação do grupo e sua inclusão nele.

Uma das áreas onde o comportamento se mostra claramente controlado pelo medo de perder a aprovação social sempre foi, sem dúvida, aquela que se refere aos comportamentos envolvendo a sexualidade. A revista O Cruzeiro (21 dezembro de 1950, p. 61) manteve, por anos, profissionais que escreviam especificamente sobre conselhos de 'bem viver'. Na década de 1950, em um desses artigos, a colunista Maria Tereza (cronista da revista O Cruzeiro: 16.01.1954, p. 61) aconselhava as moças a não permitir intimidades com os namorados, pois esses, apesar de desejá-las, esperavam que elas pusessem limite e ganhassem seu respeito. Passada uma década, a mesma preocupação ainda se faz presente em um artigo de Carmen da Silva, da revista Cláudia (dez./1963, p. 72). A colunista relata a carta de uma leitora na qual aparecia a preocupação materna em educar a filha mulher para "evitar o principal temor do que se convencionou chamar de 'mau passo'. E Carmen esclarecia que tal procedimento refletia um dos pensamentos da época: "o regime pedagógico de manter as jovens longe do demônio do sexo". Essa parece ser também a preocupação dos pais de M. L. na sua mocidade: "O pai e a mãe sempre davam uma orientação da vida. Nós mulheres tínhamos o nosso guarda-costas para sair, ir ao cinema [...] meu irmão acompanhava eu e minha irmã."

O detalhe é que esse irmão era mais novo que a entrevistada e sua irmã, a mais velha dos quatro irmãos; na impossibilidade da presença materna, a figura masculina antes da segurança física garantia o respeito à reputação das duas moças.

Tal regra parecia persistir vinte anos depois, na década de 1970. Mãe de uma filha adolescente, M. L. mantinha a obrigação de acompanhar a filha em suas atividades sociais, 
evitando "maus passos" (liberdades sexuais entre os namorados). Cabia à mãe proteger, impedir tal perda.

"Ah! Eu sempre me preocupei com ela, sempre acompanhando ela. [...]. Fiz o possível e o impossível."

Voltando à década de 1950, outro conceito, implícito, apontava a conduta social indicada para as relações amorosas. Ao iniciar o namoro, cabia à mulher tornar-se reclusa e fazer o enxoval pacatamente, enquanto o rapaz estava liberado para freqüentar os bailes sozinho. A namorada sabia e achava "natural". Das moças era esperado que deixassem o espaço público pelo doméstico, aparecendo socialmente apenas quando acompanhada pelo namorado ou familiares. A entrevistada namorava seu marido desde os 15 anos e ele tinha 17 .

“...a vida de solteira era normal. [...] eu não fui mais a festas, nada, a não ser quando ele ia para lá. As minhas amizades foram ficando mais restritas..."

“... a baile? Ah! Ia sim. A gente sabia que sim, mas nessa época achava normal, natural, ainda mais estudante, para o homem ir. Para nós não...."

O que fica claro aí é que a mulher era controlada pelo "olhar" de seus vizinhos e nem ao menos havia consciência desse fato, tal era o receio de serem rejeitadas socialmente. Havia aceitação das regras impostas como se estas fossem naturais, e mais, parecia ser esperado que o rapaz freqüentasse livremente a sociedade por ser homem, ainda mais estudante. Para Delumeau (1996, p. 59), o medo do desconhecido, que é o principal dos temores existenciais, produz a aprovação do outro, que por sua vez produz o medo do "conhecido", do julgamento alheio. "O distante, a novidade e a alteridade provocam medo. Mas temia-se do mesmo modo o próximo, o vizinho."

O "outro" acompanha a trajetória da vida adulta das pessoas. Depois de casadas, continua valendo a regra que restringe as mulheres ao lar e atribui aos homens o sustento da família. Se elas trabalham fora, têm ainda as atribuições de cuidar do lar, marido e filhos. Mais uma vez, um artigo da revista Cláudia (dez./1963, p. 124) traz à baila o assunto, ao descrever a rotina de "uma médica que atende no seu consultório e ainda chega em casa com ânimo para ajudar o marido na revisão do livro dele, alimentar a família e deitar as crianças...". A escritora chama as donas-de-casa de "pequenas rainhas tristes" pois seu reinado era uma triste carga de sucessivas obrigações. Assim foi na vida de M. L.: ela e o marido mudaram-se para o interior do Paraná; ele dedicou-se a construir uma clientela e alcançou um certo renome profissional e social, enquanto ela criava a filha e cuidava da casa. Mas, ainda assim, filiou-se a uma instituição beneficente e fez sua única experiência de trabalho externo ao lar, em prol de crianças de uma creche. Porém, mesmo aí, quando se sentira incluída e feliz num projeto que ultrapassava os limites restritos da casa, ela se via coagida pelo julgamento alheio:

“...até dinheiro na rua eu pedi. Nós pedíamos e dava vergonha. As mulheres chamavam a gente de 'vagabunda', eu 'engulia' e pensava: amanhã eu não vou! Mas ia, as crianças precisavam de nós, no dia seguinte a gente estava lá e nem se importava com isso. Fazia que não se importava [choro]... vocês não liguem. Eu ainda me emociono quando penso nisso..."

Esse relato revela alguns valores próprios de moças criadas na religião católica: devota e recatada, era sensível à opinião pública - sentimento que retoma no momento da entrevista mostrando sua dificuldade em romper com os padrões tradicionais e paternalistas de sua formação, para os quais o lugar de "mulher honesta" é dentro de casa. Nesse momento, ela teme também estar causando má impressão durante a entrevista. Pois chora e se justifica, como que se desculpando, por revelar seus sentimentos.

Nos tempos atuais, a aprovação do outro continua sendo importante, conforme afirma Zeldin: "...criar uma falsa impressão é o pesadelo moderno. A reputação é o purgatório moderno. Quanto mais democrática for uma sociedade, mais reputação ela requer e mais medo da crítica de outras pessoas, por menor que seja, se torna obsessivo" (1996, p. 160).

Na década de 1970, M. L. enfrentou a morte da mãe e temia pela segurança da família. Ao mesmo tempo teve medo de não chegar para o enterro, pois o "bom tom" mandava que uma "boa" filha estivesse a tempo para o último adeus. Mas esse medo social foi superado pelo temor existencial da morte, quando ela pede ao marido para proteger a vida da família, mesmo 
à custa de perder a despedida. Ao que parece, em algumas ocasiões os medos sociais cedem lugar aos existenciais, enquanto em outras, ocorre o oposto; o contexto define a importância.

\subsection{O medo do fracasso}

A fala de M. L. apresenta ainda uma nítida diferença entre os papéis femininos impostos pela sociedade às mulheres casadas e solteiras. Enquanto moça solteira, morava com os pais, e suas atribuições de cuidados da casa eram poucos; ao casar percebeu-se responsável por inúmeras atividades, para as quais não se sentia preparada e que ela mesma se cobrava por acreditar no dever fazê-lo adequadamente. Não corresponder a esses papéis seria, a seu ver, fracassar:

“Ah! Faz muita falta a mãe. Ainda mais eu que minha mãe sempre teve empregada, eu não fazia nada e agora tinha que fazer tudo. De repente ter que assumir uma casa. Antigamente era a gente que tinha que assumir. [...] não foi fácil! às vezes errava tudo, queimava. Meu Deus, como a gente se batia".

Era isso que era esperado dela; esse era seu trabalho e não poderia fracassar.

Uma prática social, recentemente instituída, o exame vestibular, como forma de passaporte para a vida profissional, é ocasião em que os que fracassam ficam de fora. Para M. L., a prova de competência que Ihe conferia direito ao mundo adulto era cuidar com perfeição da casa (década de 1950). Para seus filhos, essa prova de competência seria passar no vestibular (década de 1980):

"Fiquei nervosa [...]. A gente quer que eles passem, tenham êxito. Parece que quando eles passam a alegria é para eles e para a gente. Até para a gente é mais, sabendo que eles vão vencer, vão ser... e eles passaram... a menina já era casada quando fez o vestibular, terminou já com filhos. [...] passou no primeiro lugar. O menino não [...]. No ano seguinte ele passou em três faculdades..."

O nervosismo ante a prova a que os filhos iriam ser submetidos aparece como medida de competência, não só deles, mas também dela - e da educação que lhes dera perante a comunidade. $\mathrm{E}$ ao passarem, conferiam, também a ela, uma vitória pessoal. $\mathrm{O}$ ter passado no primeiro vestibular, e em primeiro lugar, faz diferença no reconhecimento do "outro".

Ao obterem sucesso, os seres são aprovados por seus pares, adquirem o direito a uma filiação que Ihes dá segurança. Duby, (1998) diz que, ao pertencer a grupos, ao ser escolhido por outros, a solidão, uma grande inimiga do homem, é afastada.

\subsection{O fantasma da solidão}

Ainda é Duby quem diz: "... a solidão que acompanha a miséria de hoje era desconhecida dos nossos ancestrais dos anos mil." (1998, p. 38). A diferença entre as sociedades do milênio 1000 e o 2000, é que, na Idade Média, o homem se apresentava como um ser social e solidário, confiante no seus "pares". Agora está solitário, desconfiado de tudo, de todos.

"...Acho que cada um está cuidando de sua vida e ainda assim não dá conta. Feliz de quem tem

algo para se preocupar, tem gente que não tem nem família"

Essa afirmação de M. L. tem a ver com o pensamento de Duby, para quem a sociedade, ao se preocupar com o bem-estar de seus membros adquire segurança, além de conforto. $\mathrm{Na}$ opinião de M. L. é feliz quem tem família, isso é, essa é quem se preocupa, quem cuida, é o olhar do outro voltado para o indivíduo, protegendo. Porém, como diz Zeldin (1999, p.72) ao resolver o problema existencial do desconhecido, vivendo em comunidade, o homem criou outro perigo, dessa vez a ameaça de perder o que é "conhecido". Perdê-lo, ficar só, pode ser algo que tire a tranqüilidade e ocasione ansiedade.

A sensação de estar sozinha aparece de modo implícito no relato de como M. L. sentira o casamento dos filhos:

“...Quando minha filha casou, eu tinha a M. comigo [irmã], mas quando a M. saiu eu senti. Casou o menino em junho e a M. em setembro."

Quando a irmã dela casou e saiu da cidade, a filha morava longe e o filho recém havia casado, então a solidão se instalou. 
É de se presumir que, como diz Delumeau, os medos sofram transformações contextuais. Uma mesma pessoa ao longo de sua trajetória de vida temerá situações diferentes, ou por ter adquirido repertório para lidar com o perigo, ou porque esse deixou de ser o inimigo. $O$ casamento para uma jovem da década de 1950 era algo a ser mantido a todo custo. Os periódicos da época traziam "conselhos" às jovens casadouras ou recém-casadas, para "segurar" o marido. O jornal $A$ Tarde, (jun./1957, p. 5) apresentava 15 mandamentos de como comportar-se para prender seu marido. Parece que tal preocupação vai diminuindo ao longo do tempo. Ou a mulher ficou mais segura ou a relação, amadurecendo, permitiu mais segurança; no depoimento de $M$. L. não fica claro o que está causando a mudança, mas sim, que houve uma mudança nos valores e sentimentos. Ao ser questionada sobre o seu relacionamento com o marido e a preocupação que normalmente se tinha de conservar o casamento para as jovens de sua geração, ela retruca:

\section{"É claro. Quando era moça, depois não mais. A gente fica mais segura depois de uma certa idade."}

A família e os vizinhos exerciam uma grande forma de controle sobre os jovens dos anos 50 , como já demonstrado por M. L. na sua fala sobre a preocupação com os outros. Ao longo do tempo, essa preocupação foi sendo substituída, para ela, por seu oposto. O 'outro' perdeu a capacidade de controlar o comportamento social e o perigo é justamente o estar só, a ausência do olhar do outro:

"A gente não tinha essa preocupação quando os filhos da gente saíam. [...] a gente não ficava até tão tarde na rua. Meus netos são comportados, mas preocupa saber que estão na rua. [...]"

\section{CONSIDERAÇÕES FINAIS}

Investigar as emoções que acompanham as relações sociais entre os humanos pode fornecer ao pesquisador social uma fonte fidedigna sobre os valores e normas culturais que controlaram a sociabilidade de uma determinada época. Delumeau, Lefebvre, Chauí e Zeldin falam dessa emoção - o medo - que é compartilhada por todos os homens e que faz parte das suas relações com a natureza, consigo mesmo e com o outro sempre que essas impliquem perigo.

Os medos existenciais (os permanentes), embora partilhados por todos os humanos, sofrem influência da inserção social daquele que os possui e se transformam durante a trajetória de vida das pessoas. Então, saber como as pessoas reagem em face das situações que envolvem a própria morte, a morte dos seres amados e demais perdas significativas, o novo e portanto imprevisível, e nesse caso incontrolável, pode ser uma forma de conhecer as regras da sociabilidade humana.

Zeldin afirma, em convergência com Delumeau, que existem medos que são comuns a todos os humanos e que auxiliaram a humanidade a ser da forma que hoje é conhecida, isto é, auxiliou-a a se defender daquilo que poderia causar sua extinção. Ambos os autores concordam que, ao se agruparem, os homens construíram barreiras a essa possibilidade de perecer; enquanto associados, os homens conseguiram superar perigos que sozinhos não teriam superado. Nessa "comum unidade", o ser humano superou-se em criatividade e audaciosidade. Mas... Sartre afiançou que o inferno do homem é o outro . Chauí o contradiz, ao afirmar que o inferno do homem é ele mesmo. Zeldin fala que, à medida que é bem-sucedido em construir defesas a perigos atuais, o ser humano acaba por construir novos perigos. Por milhares de anos o agregar-se acabou com o perigo do desconhecido e instituiu o "olhar" do outro (opinião pública) como vigia e protetor; simultaneamente esse outro transformou-se no algoz que dita regras e poda a liberdade. Hoje o homem está de novo sozinho, perdido no meio de uma multidão de "iguais" que nunca foram tão iguais na sua necessidade de carinho, da aprovação do outro, da filiação.

Duby afirma que o grande medo atual parece ser o medo da solidão, que é a mãe da violência, e assim volta-se ao perigo de sofrer a morte, senão a biológica ,a da maior das características humanas: a afetividade, o importar-se com o outro!

No depoimento de M. L. constata-se a presença dos medos existenciais propostos na fala de Delumeau, analisados nas obras de Chauí, Lebfreve e Ariés. Eles estão ali relatados de 
uma forma permitida somente ao final do século XX, falar das próprias emoções. Mas, mesmo esses medos sofrem mutação ao longo da existência da pessoa que fala. Ao rememorar, M. L. descreve junto com suas emoções, as regras sociais pertinentes ao momento social em que os fatos de sua vida foram ocorrendo. No seu depoimento, os medos existenciais estão presentes como para qualquer outra pessoa, mas expressos de acordo com a forma que lhe foi imposta pela cultura.

Está presente também a segunda categoria de medos, aqui chamados de medos sociais. Construída pelas relações sociais, a necessidade de ser aprovado pelo outro gera comportamentos ditados por regras sociais que impedem tal perda; da mesma forma seria terrível fracassar, pois que isso geraria a solidão, a desfiliação. Com isso surge um novo grande inimigo, próprio dessa transição de século e de milênio: cada um por si e nenhuma regra solidária a proteger o homem de si mesmo e de sua provável destruição. As lembranças pessoais apresentadas por M. L. parecem refletir mais que sua memória individual e identificar as relações sociais partilhadas por um grande número de sujeitos.

O "olhar" do vizinho (medo social) garantia contra a violência. A liberdade era sacrificada, mas a segurança física era garantida (medo existencial); hoje isso já não ocorre: "Feliz de quem tem algo para se preocupar, tem gente que não tem nem família" é a frase com que M. L. encerra seu depoimento.

\section{FONTES e REFERÊNCIAS BIBLIOGRÁFICAS}

\section{FONTES ESCRITAS:}

Periódicos da Biblioteca Pública do Paraná:

a) Revistas: O Cruzeiro e Cláudia

b) Jornal: $A$ Tarde. Curitiba/PR

2. FONTE ORAL:

Entrevista gravada em 06.09.2000, com M. L. (dona de casa de 68 anos)

\section{REFERÊNCIAS BIBLIOGRÁFICAS}

Ariés, P. (1977). História da morte no Ocidente: Da idade média aos nossos dias. Rio de Janeiro: Francisco Alves.

Chauí, M. (1987). Sobre o medo. Em S. CARDOSO (Org.), Os sentidos da paixão. São Paulo: Companhia das Letras.

Delumeau, J. (1996). História do medo no Ocidente: 1300-1800. Uma cidade sitiada. São Paulo: Companhia das Letras.

Duby, G. (1998). Ano 1000 ano 2000 na pista de nossos medos. São Paulo: UNESP.

Elias, N. (1994). A sociedade dos indivíduos. Rio de Janeiro: Zahar.

Ginzburg, C. (1992). O queijo e os vermes: O cotidiano e as idéias de um moleiro perseguido pela inquisição. São Paulo: Companhia das Letras.

Lebfreve, G. (1979). O Grande Medo de 1789. Os camponeses e a revolução Francesa. Rio de Janeiro: Campus.

Maria Tereza (?). (1954, 16 de janeiro). Quando o homem é mais fraco. Revista O Cruzeiro, Rio de Janeiro: Bloch. p. 81.

Matos, M. I. S. (1997). Outras histórias: As mulheres e estudos. Em E. M. SAMARA (Org.), Gênero em debate: Trajetória e perspectivas na historiografia contemporânea. São Paulo: EDUC.

Queiroz, R. (1950, 01 de março). Luzes nas sombras. Revista O Cruzeiro, Rio de Janeiro: Bloch.

Rosângela (1957, junho). Se quer prender seu marido. Jornal $A$ Tarde, Curitiba: ano VIII. p. 5.

Saffioti, H. (1979). A mulher na sociedade de classe: Mito e realidade. São Paulo: Vozes.

Sartre, J. P. (1977). Entre quatro paredes. São Paulo: Abril Cultural.

Soihet, R.; Matos, M. I. S. (1997). Gênero em debate: Trajetória e perspectivas na historiografia contemporânea. São Paulo: EDUC.

Silva, C. (1963, novembro). A arte de ser mulher. Revista Cláudia, n. 27, ano III. p. 124.

Silva, C. (1963, dezembro). A arte de ser mulher. Revista Cláudia, n. 28, ano III. p. 72. 
Zeldin, T. (1999). História íntima da humanidade. Rio de Janeiro: Record. 